\title{
Etikk i forskning og fagutvikling
}

\author{
Artikkelen omhandler juridiske og etiske aspekter ved ulike typer \\ fagutviklings- og forskningsprosjekter.
}

\begin{abstract}
or mange sykepleiere er bacheloroppgaven den første øvelsen i eget vitenskapelig arbeid. Sykepleiere møter stadig krav om forskningsbasert praksis. Som sykepleiere kan vi ha prosjektansvar selv, være informanter eller ha ansvar for pasienter som er forskningsobjekter.
\end{abstract}

\section{Godkjenning}

Når man planlegger et prosjekt må man vurdere hvilke data man trenger for å besvare de problemstillingene man definerer. Ansatte i praksisfeltet har ofte tilgang på sensitive data, men det har ikke automatisk eksterne samarbeidspartnere. Skal et prosjekt ha framdrift, er det ofte behov for tett oppfølging fra en person som ikke har klinisk ansvar. For å starte et prosjekt, må den faglige- og administrative ledelsen ved institusjonen gi sitt samtykke. Mange prosjekter trenger godkjenning fra Norges samfunnsvi-

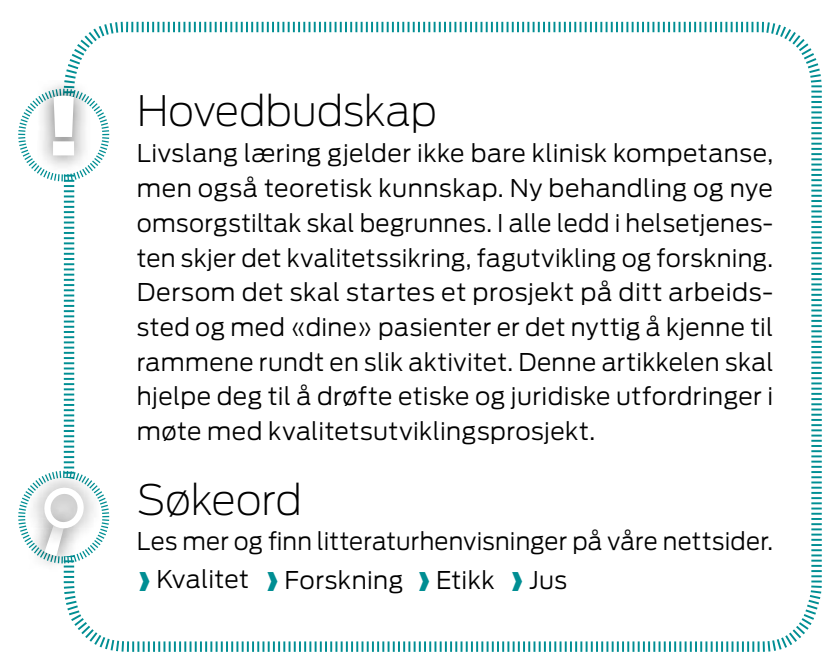

tenskapelige datatjeneste (NSD) eller Regional etisk komité for medisinsk og helsefaglig forskning (REK).

\section{NSD}

I flere prosjekter har man behov for å lage en liste over personer som deltar. I så fall må man søke om godkjenning fra NSD. Formålet med personopplysningsloven er å verne den enkelte mot krenking av personvernet gjennom bruk av personopplysninger (1). NSD er personvernombud for forsker- og studentprosjekter som gjennomføres ved alle universiteter og høyskoler, en rekke helseforetak og andre forskningsinstitusjoner (2).

\section{REK}

Godkjenning fra REK er nødvendig dersom man skal starte et forskningsprosjekt som omfatter medisinske og helsefaglige spørsmål. Helseforskningslover (3) setter klare rammer for forskning hvor mennesker er involvert. Veiledningen til Helseforskningsloven gir gode råd (4). REK er hjemlet i forskningsetikkloven (5) og helseforskningsloven (3). I alle de syv regionale komiteene er det en representant som er anbefalt av Norsk Sykepleierforbund. Komiteene oppnevnes av Kunnskapsdepartementet for fire år om gangen.

\section{Informert samtykke}

Et sentralt anliggende når det gjelder søknadsskjema både til NSD og REK er informert samtykke. Forespørselen skal inneholde viktig informasjon om hva studien innebærer, mulige fordeler, ulemper og alvorlige bivirkninger. Man skal også forklare hva som blir gjort med medisinske prøver eller annen informasjon som er innhentet. Det skal presiseres at det er frivillig å delta i studien. Vedkommende kan når som helst trekke seg fra studien uten at det får noen konsekvenser. Man tar bare kontakt med informanten etter aktivt samtykke, enten fra personen selv eller fra den aktuelle pårørende.

\section{Kvalitetssikring}

Hensikten med fagutvikling er å øke kompetanse for å heve kvalitet på et angitt satsingsområde. Eksempler på dette kan være sårbehandling, omsorg for aldersdemente pasienter eller ernæringssvikt hos eldre. Kvalitetssikringsprosjekt består av data som samles inn som en del av de etablerte rutiner på aktuelle omsorgsnivå for alle pasientene. Ethvert foretak har ansvar for å sørge for kvalitetssikring, innenfor de rammer som krav til personvern setter. Når ansatte undersøker og registrerer data som et ledd i sine daglige rutiner, kreves det ikke godkjenning fra REK. Grensen mellom kvalitetssikring og forskning relatert til beboere kan ofte være uklar (6). Det viktigste er at man ønsker å innhente ny kunnskap, uansett om det er definert som forskning eller kvalitetssikring. Et viktig anliggende i denne sammenhengen er formålet med virksomheten (7).

\section{Forskning}

I helseforskningsloven § 4 (3) er medisinsk og helsefaglig forskning definert som «virksomhet som utføres med vitenskapelig metodikk for å skaffe til veie ny kunnskap om helse og sykdom». Et forskningsprosjekt skal ha klare hypoteser eller forskningsspørsmål. Prosjektbeskrivelsen skal gi teoretisk rammeverk og vise til relevant forskning innen samme tema. Ifølge helseforskningsloven § 2 (3) faller forskning på 


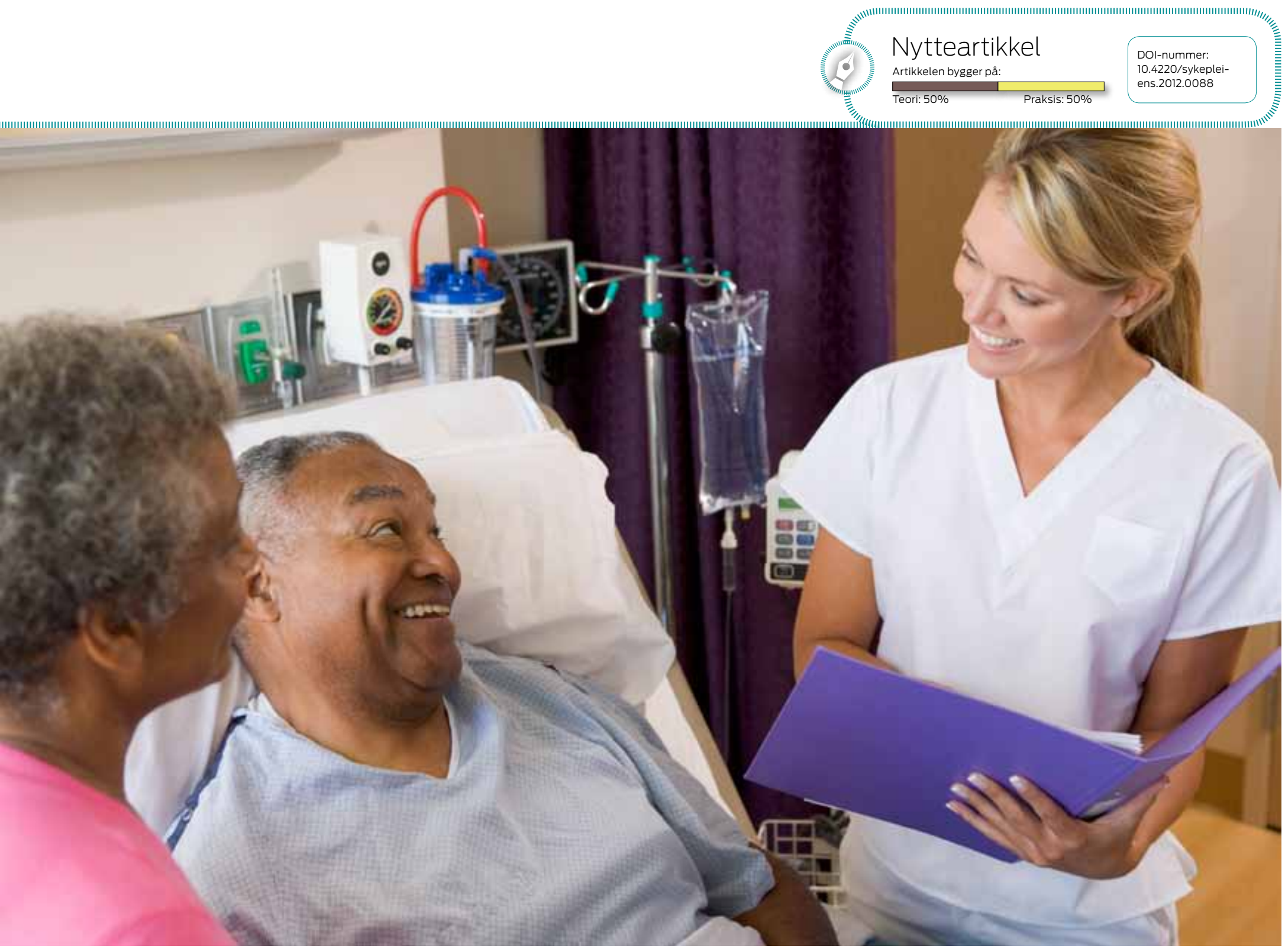

PERSONVERN: Hvis man har behov for å lage en liste over personer som deltar i et forskningsprosjekt må det godkjennes av Norges samfunnsvitenskapelige datatjeneste. Illustrasjonsfoto: Colourbox.

anonyme data utenfor loven der det ikke har vært direkte kontakt mellom forsker og deltaker. Det er viktig å skille mellom avidentifiserbare og anonyme data. Ofte benytter man begrepet «Anonyme på forskers hånd». Det vil si at det eksisterer en kodenøkkel som blir oppbevart hos en ansvarlig instans utenfor forskerens rekkevidde. Data som blir innhentet av ansvarlig personale, uten at forsker møter pasienten kan derfor leveres anonymisert til forsker - og faller uten for REK's ansvar (8).

\section{Fra idé til prosjekt}

Ofte er det én person som får ideen til et prosjekt. Det er viktig å få bekreftet om temaet kan danne grunnlag for gode problemstillinger. Man må velge en metode som ut fra kompetanse og ressurser gir best svar på de spørsmålene man stiller.

Som sykepleiere har vi tilgang på sensitive opplysninger. Det er klare retningslinjer for hvordan disse dataenes skal håndteres helsepersonelloven \$ 21 (1). Taushetsplikten skal ikke være til hinder for medisinsk- eller helsefaglig forskning (ibid.: § 29). Et sentralt juridisk og etisk anliggende i forhold til medisinsk og helsefaglig forskning blir hvordan forskerne skal få tilgang på data. Dersom man trenger personopplysninger er det nødvendig å skille mellom tre ulike hovedtyper: identifiserbare, avidentifiserbare og anonyme.

Direkte identifiserbare opplysninger er opplysninger som har navn eller fødselsnummer knyttet til seg. Avidentifiserte opplysninger er opplysninger der identifikasjon skjer indirekte ved et løpenummer eller en annen opplysning som peker tilbake på en identifikasjon. Avidentifiserte opplysninger skal tilsvare anonyme opplysninger, bortsett fra at datasettet kan inneholde en nøkkel som peker tilbake til en personidentifikator. For den som ikke har tilgang til nøkkel-registeret, er opplysningene anonyme. Fordi man teknisk sett kan reidentifisere dem, regnes de som avidentifiserte (9).

\section{Ulike prosjekttilnærmingsmåter :}

\section{a) Kompetanseutvikling}

En gruppe sykepleiere får opplæring i å legge medisiner i multidoser i en større hjemmesykepleieenhet. De deles i to grupper. Gruppe B skal dele ut medisinene som gruppe A har dosert, og gruppe A skal dele ut medisinene som gruppe B har dosert. Alle sykepleierne har tilgang til opplysninger om aktuelle pasienter. Prosjektet varer i fire uker. Det blir skrevet avviksmeldinger og hver uke får gruppe $\mathrm{A}$ og $\mathrm{B}$ veiledning i forhold til vanlige feil og kunnskap om konsekvensene av aktuelle feilmedisineringer.

Kommentar: Ledelsen vurderte dette som et kompetanseutviklingsprosjekt og ingen eksterne instanser ble kontaktet. Medikament-

\section{«Å organisere et slikt undervis- ningstilbud kan redusere avvik.»}

håndtering er en viktig del av sykepleiernes funksjonsområde. Å organisere et slikt undervisningstilbud kan redusere avvik.

\section{b) Kvalitetssikring}

Det skal testes ut et nytt skjema som omhandler livskvalitet hos sykehjemsbeboere (10). Skjemaet er oversatt fra engelsk. Hensikten er å se om spørsmålene fungerer både språklig, innholdsmessig og relasjonsmessig. To eksterne sykepleiere (mastergradsstudenter) skal gjennomføre intervjuene. Ledelsen ved et sykehjem 
blir kontaktet og de får en skriftlig forespørsel som inneholder en prosjektbeskrivelse og intervjuskjemaet. Skjemaet inneholder alder og kjønn, men ellers ingen andre personidentifiserbare opplysninger. Det skal ikke stilles spørsmål om diagnoser eller andre konkrete spørsmål om helseforhold. Beboerne skal være samtykkekompetente. Sykehjemmet ønsket og delta og 20 beboere var villige til å la seg intervjue. Det ble presisert at beboerne sto fritt til å vurdere i hvilken grad de ville besvare alle spørsmålene.

\section{«Det var ikke sykepleiernes livs- kvalitet det skulle forskes på.»}

Samtalene skulle gjennomføres i løpet av to dager, cirka trekvart time per beboer.

Kommentar: Hensikten var å teste ut spørreskjemaet. Dersom skjemaet fungerte bra, ville det bli benyttet $\mathrm{i}$ andre sammenhenger senere. Ved å velge beboere i sykehjem trengte ikke studentene opprette noe personregister, og undersøkelsen krevde derfor ingen godkjenning fra NSD. Skjemaet inneholdt ingen helseopplysninger og falt derfor utenfor REK sitt mandat.

\section{c) Personregister}

Mastergradsstudentene hadde vurdert dataene fra intervjuene med eldre og deres selvrapporterte livskvalitet. Den norske oversettelsen var blitt justert, og studentene ønsket nå å få sykepleierne til å vurdere hvordan de opplevde beboernes trivsel og livskvalitet. Det var derfor viktig at beboerens primærpleier skulle intervjues. Planen var å inkludere alle beboerne på to poster, til sammen 50 beboere. Disse pasientene behøvde ikke være samtykkekompetente. Denne gangen var det sykepleierne som skulle intervjues, og det var deres vurdering som skulle dokumenteres. Ledelsen svarte ja til denne oppfølgingsstudien. De som ble invitert til å delta måtte enten være offentlig godkjente sykepleiere eller hjelpepleiere. Pleietjenesten var organisert som primærteam, og målet var å få med 20-25 pleiere. På hver av postene var det et par av pleierne som ikke ville underskrive et informert samtykke, og andre i teamet ble forespurt.

Kommentar: Det var ikke opplagt for studentene at det var nødvendig å få informert samtykke fra sykepleierne når pasientene ikke trengte å gi et slikt samtykke. Det var ikke sykepleiernes livskvalitet det skulle forskes på. Veileder forklarte at det å innhente skriftlig samtykke var en forsikring ikke bare for sykepleieren som ga informasjon, men også for studentene selv. Skriftlig informert samtykke gjorde det mulig å kontrollere at opplysningene som ble gitt var blitt notert korrekt og benyttet etter hensikten med intervjuet. Studentene skulle spørre informantene om de ønsket å se utskrift av kvalitative utsagn som kunne benyttes i mastergradsoppgaven. Veileder var også nå klar på at dette neste trinnet av prosjektet heller ikke trengte legges frem for REK. Studentene la frem sine planer på et seminar for mastergradsstudenter. En medstudent lurte på om de hadde søkt datatilsynet om tillatelse til å opprette personregister. Studenten argumenterte med at cirka 20-25 pleiere skulle intervjues. Informantene skulle også få tilsendt utskrifter av intervjuet. Mastergradsstudentene måtte sette seg raskt inn i søknadsprosedyrene til Norsk samfunnsvitenskapelig datatjeneste (NSD), og fikk en ufrivillig pause i datainnsamlingen.

\section{d) Forskningsprosjekt}

Mastergradsstudentene avsluttet sitt arbeid og leverte hver sin oppgave om ulike aspekter ved måling av livskvalitet hos sykehjemsbeboere. Veilederen deres vurderte livskvalitetsskjemaet til å fungere så bra at hun anbefalte to nye studenter å gå videre med et nytt prosjekt. Studentene ble forespurt i oppstarten av studien, slik at de kunne få god tid til å planlegge. Denne gangen ble to sykehjem i en middels stor landkommune valgt. Studentene skulle selv intervjue de pasientene som ble vurdert av avdelingsleder til å være samtykkekompetente, mens sykepleiere og hjelpepleiere skulle bli intervjuet i forhold til pasientene med kognitiv svikt. De planla å inkludere cirka 50 beboere fra hvert sykehjem. I tillegg til intervjuskjemaet skulle det innhentes opplysninger angående diagnose, medikamenter og fysisk funksjon fra den elektroniske pasientjournalen. Hensikten var å vurdere sammenheng mellom livskvalitet og somatisk lidelse. Avdelingslederne skulle oppbevare en nummerert navnliste. De selvrapporterte livskvalitetsskjemaene samt et eget skjema for helseopplysninger skulle påføres et korresponderende nummer.

Kommentar: Denne studien krevde bruk av helseopplysninger. Studentene hadde i sine prosjektskisser formulert klare forskningsspørsmål. Det måtte innhentes skriftlig samtykke fra pasientene og der pasientene ikke var samtykkekompetente, fra deres nærmeste pårørende. Veileder var tydelig på at denne studien var fremleggelsespliktig for Datatilsynet og REK. Planen var at sykepleierne på de ulike avdelingene skulle hente ut helseopplysninger fra den elektroniske journalen og overføre dem til helseskjema. Dataene ble derved avidentifisert og «på forskers hånd».

\section{Praktiske råd}

Søknadsskjemaene til REK med tilhørende veiledningsdokument har sentrale punkter som man kan bruke i prosjektbeskrivelsen. Man må beskrive om prosjektet har samfunnsmessig nytte, om informert samtykke fra fors $ø$ kspersonene ble innhentet på en forsvarlig måte og om informasjonsskrivet inneholder tilstrekkelige opplysninger for dem det gjelder. Man må vurdere om prosjektet vil kunne medføre ulempe for noen av de involverte partene. Man må også nøye beskrive hvordan persondata blir anonymiserte slik at et adekvat personvern er sikret.

Et positivt vedtak fra en slik søknad til REK kan være som følgende: Komiteen har vurdert søknaden og godkjenner prosjektet med hjemmel i helseforskningsloven $\S 10$ (2). Det knytter seg imidlertid vilkår til godkjenningen som man må oppfylle før man setter prosjektet i gang.

Godkjenningen omfatter: Tillatelse til å opprette forskningsprosjekt, helseforskningsloven § 10. I tillegg til vilkår som fremgår av dette vedtaket er tillatelsen gitt under forutsetning av at prosjektet gjennomføres slik det er beskrevet i søknaden, protokollen og de bestemmelser som følger av helseforskningsloven med forskrifter.

Ut fra det jeg har nevnt ovenfor setter komiteen følgende vilkår for prosjektet: Komiteen understreker nødvendigheten av at intervjuerne gjøres ekstra oppmerksomme på at beboere uten samtykkekompetanse kun skal inkluderes i prosjektet, dersom samtykke foreligger fra den nærmeste pårørende.

Vilkår vedrørende informasjonssikkerhet: Komiteen forutsetter at man oppbevarer data i avidentifisert form. Det vil si at opplysningene oppbevares uten direkte personidentifiserbare parametre, men hvor man kan finne tilbake til den personen opplysningen stammer fra ved hjelp av en nøkkel eller kode (4).

\section{Gjennomføring av studie}

Intervjuene med pleiepersonalet angående vurdering av beboernes livskvalitet gikk greit. Studentene hadde laget en god fremdriftsplan som var innordnet etter pleiernes vaktturnus og tidspunkt på dagen som var noe roligere. Når det gjaldt uthenting av helseopplysningene fra den elektroniske journalen, var det svært vanskelig for sykepleierne å prioritere dette. For studentene skapte dette problemer på grunn av 
tidsrammene for mastergradsstudien. Etter samtaler med veileder og ledelsen for sykehjemmet ble man enige om å sende en endringss $ø$ knad til REK angående fritak fra taushetsplikten, slik at de selv kunne hente ut materiale fra den elektroniske journalen.

Departementet har delegert myndighet til REK om at helseopplysninger kan gis til bruk i forskning, og at det kan skje uten hinder av taushetsplikt etter helsepersonelloven \$ 29 (11). Til slikt vedtak kan det imidlertid være knyttet visse vilkår. Studentens endringss $ø$ knad ble behandlet i REK, men det ble ikke funnet grunnlag for å gi studentene tillatelse til selv å innhente sensitive opplysninger. De ble anbefalt å «frikjøpe» en ansatt som hadde adgang til data, slik at de kunne få opplysningene i avidentifisert form.

\section{Publisering}

Studentene fikk hjelp av en statistiker til å analysere data. De fant flere interessante resultater. Veilederen deres anbefalte dem å skrive en forskningsartikkel. De mest interessante funnene var knyttet til student A's mastergradsoppgave. Det var derfor naturlig at hun var førsteforfatter, på den andre siden var A høygravid og regnet med å få liten tid til skrivearbeid. Student B, som fikk den største arbeidsbyrden, ble førsteforfatter og student A andreforfatter. Statistikeren, som i tillegg til den tekniske siden ved dataanalysen bidro med faglige innspill, ble 3 . forfatter, veilederen ble 4. forfatter og sto til sist. Da mente sykepleierne at «Hanne Olsen», som hadde brukt betalt fritid på å hente ut helseopplysninger fra den elektroniske journalen, også burde være medforfatter. Hun hadde dessuten vært med på å organisere en plan for intervjuer med pleierne. Rent pedagogisk og psykologisk ville det vært riktig å også inkludere en fra praksisfeltet, men vedkommende hadde ikke bidratt tilstrekkelig til undersøkelsen. Vancouver-gruppens forfatterskapskriterier legger vekt på at den enkelte må ha oppfylt alle tre følgende kriterier for å være forfatter: 1) ha betydelige bidrag til unnfangelse og design, datainnsamling, eller analyse og tolkning av data, 2) utarbeide artikkelen eller revidere den kritisk for viktig intellektuelt innhold, og 3) gi endelig godkjenning av versjon til publisering. Alle forfattere bør oppfylle betingelsene 1, 2 og 3 (12).

\section{Sitering og kilder}

Et viktig anliggende i forhold til etikk og redelighet innenfor fagutvikling og forskning er korrekt bruk av sitater og referanser. Ved sitatfeil er det nærliggende å anta at forfatterne ikke har lest originalartikkelen eller at vedkommende ikke har forstått innholdet. Sitering reflekterer det akademiske arbeidet til forfattere og tidsskriftet, og dårlig sitering reduserer verdien av publiserte artikler (13-14). En vanlig feil er å sitere redaktøren av en antologi og ikke forfatteren av det aktuelle kapitlet. Det blir også ofte referert til eller sitert fra en artikkelforfatter og ikke de teoretikerne eller forskerne som har utført den aktuelle undersøkelsen som omtales. Dersom man må benytte sekundære kilder skal dette angis tydelig.

\section{Oppsummering}

Det stilles strenge etiske og juridiske krav til alle prosjekter som omfatter helseopplysninger. Ved planlegging av et prosjekt må man tenke nøye over hvilke data det er nødvendig å innhente. Dersom man er usikker på om prosjektet skal kategoriseres som kompetanseutvikling, kvalitetssikring eller forskning, bør man søke hjelp hos den faglige ledelsen på praksis- og eventuelt studiestedet. Ethvert prosjekt som inneholder personopplysninger og skal bearbeides digitalt trenger godkjenning fra Datatilsynet. Forskningsprosjekt som omfatter medisinske og helsefaglig spørsmål krever REK-godkjenning. Enhver publikasjon må overholde internasjonale regler for forfatterskap, bruk av sitat og referanser. III

\section{LITTERATUR}

Lov av 14. april $2000 \mathrm{nr}$. 31 om behandling av personopplysninger (personopplysningsloven) (www.lovdata.no).

Norge Samfunnsvitenskapelige datatjeneste (NSD). Meldeskjema for Personvernombudet for forskning.) Bergen: Universitetet i Bergen; 2009.

3. Lov av 20. juni $2008 \mathrm{nr}$. 44 om medisinsk- og helsefagligforsking (helseforskningsloven) (www.lovdata.no).

4. Helse- og omsorgsdepartementet. Veileder til lov av 20. juni $2008 \mathrm{nr} .44$ om medisinsk og helsefaglig forskning (helseforskningsloven). http://www. om medisinsk og helsefaglig forskning (helseforskningsloven). http://www. ven.pdf4. 5. Lov av 30. juni $2006 \mathrm{nr}$. 56 om etikk og redelighet i forskning ven.pdf4. 5. Lov av 30. juni $2006 \mathrm{nr}$. 56 om
(forskningsetikkloven) (www.lovdata.no). Utne PH, Thelle DS. Kvalitetssikring eller forskning? Tidsskr Nor Legeforen. 2009; Nov 19; 129(22): 2385.

7. Ruyter KW. Etikk i forskning Sykepleien Forskning - Om forhåndsgodkjenning av forskningsprosjekter i regionale etiske komiteer. 2010; 5(1):72-8.

8. Simonsen S, Hølen J. Er forskningsprosjekter med innsamling av anonyme data å anse som forskning på mennesker? Forskningsetikk. 2010; 10(1):22-3.

9. Langtvedt NJ. Personopplysninger. 2009. http://www.etikkom.no/FBIB/ Temaer/Personvern-og-ansvar-for-den-enkelte/Personopplysninger/ LOV-2006-06-30 nr. 56

10. Sørbye LW, Grue EV, Vibe 0. Trives på sykehjem. Sykepleien 2011;99, 8:68-71.

11. Lov av 2. juli1999 nr.64 om helsepersonell m.v. Helsepersonelloven med endringer, sist ved lover av 27.juni $2008 \mathrm{nr}$. 65 ( $\mathrm{i}$ kraft 1. januar 2009) og av 14. november $2008 \mathrm{nr}$. 80.) 2009

12. The International Committee of Medical Journal Editors Uniform requirements for manuscripts submitted to rements for manuscripts submitted to biomedical journals: ethical considerabion

13. Schulmeister L. Quotation and reference accuracy of three nursing journals. Image J Nurs Sch. 1998: 30(2): 143-6.

14. Gosling CM, Cameron M, Gibbons PF. Referencing and quotation accuracy in four manual therapy journals. Man Ther 2002; Feb; 9(1): 36-40.

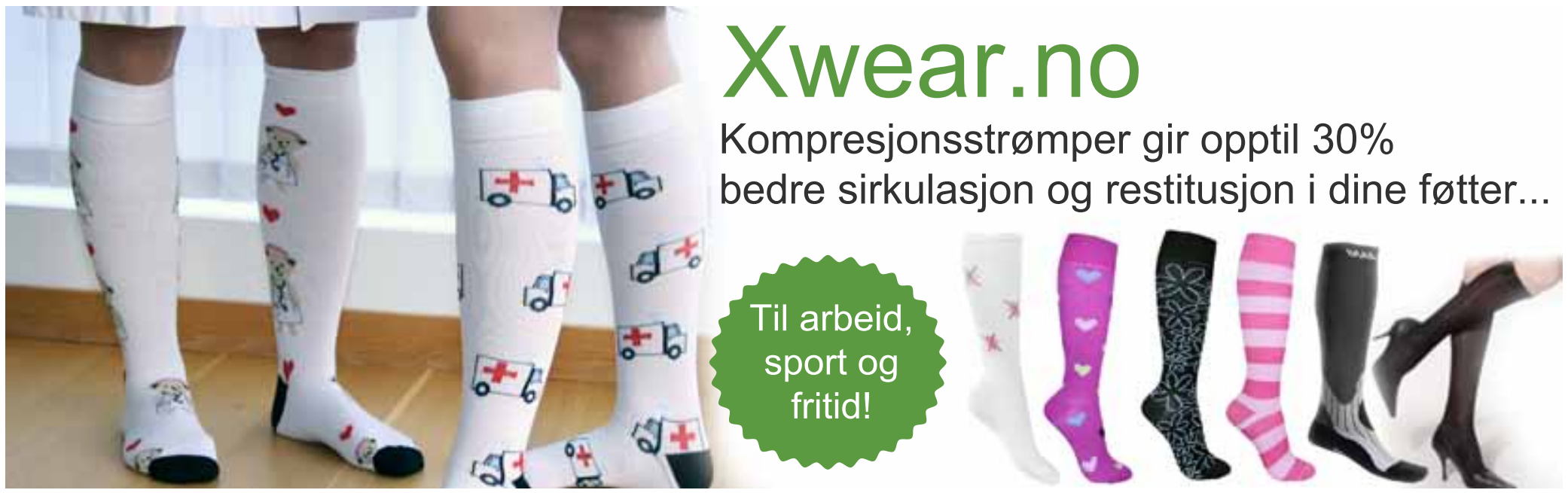

